\title{
Spawn Production and Return on Investment of Four Varieties of Mushroom (Pleurotus florida, Pleurotus ostreatus, Ganoderma lucidum and Calocybe indica) Using Sawdust Media
}

\author{
${ }^{1}$ Abdani D. Bandera \\ Mindanao State University-Buug, \\ Zamboanga Sibugay, Philippines
}

\author{
${ }^{2}$ Jamelah A. Bandas \\ Mindanao State University-Main, \\ Marawi City, Philippines
}

\begin{abstract}
The study was conducted to determine the mycelial performance of the four varieties of Mushroom using sorghum grains as sterile media at the Mushroom Research Center (MRC), College of Agriculture, Mindanao State University, Marawi City. In particular, the study aimed to evaluate the length of mycelia, width of mycelia, and its Return on Investments (ROI). Completely Randomized Design (CRD) was used with four (4) treatments replicated three times. Treatments were $\left(\mathbf{T}_{1}\right)$ Pleurotus florida, $\left(\mathbf{T}_{2}\right)$ Pleurotus ostreatus, ( $\left.\mathbf{T}_{3}\right)$ Ganoderma lucidum, $\left(\mathbf{T}_{4}\right)$ Calocybe indica. Results of the study showed that spawn production revealed non-significant differences in terms of length and width of mycelia. In terms of its return on investment (ROI), lower ROI was recorded in $\mathrm{C}$. indica.
\end{abstract}

Keywords:- Mushroom, sorghum, mycelia, spawn production, return on investment (ROI), Pleurotus florida, Pleurotus ostreatus, Ganoderma lucidum, Calocybe indica.

\section{INTRODUCTION}

In the Philippines, mushroom is rarely observed in the market. Most Filipinos are deemed mushroom consumers. However, the availability of the produce is found absent in most of the marketplace. In addition, farmers are technically less aware and educated on mushroom production. Thus, the need to produce this commodity is found significant especially the production of spawn to sustain the demand of the consumers.

[6] pointed out that mushrooms are regarded as a macro-fungus with a distinctive fruiting body which can be either epigeous or hypogeous and large enough to be seen with the naked eyes and to be picked by hand. mushrooms are nutritionally endowed fungi (mostly Basidiomycetes) that grow naturally on the trunks, leaves and roots of trees as well as decaying woody materials [26, 17]. These mushrooms include Agaricus spp. (button mushrooms), Volvariella volvacea (oil palm mushrooms), Auricularia auricula (wood ear mushroom), as well as Pleurotus ostreatus (oyster mushrooms).

[12] and [29] identified that $P$. ostreatus, an oyster mushroom, is primarily consumed for its nutritive value and is used industrially as a bioremediator. Nutritionally, the mushroom has been found to contain vitamins thiamin, riboflavin, niacin, pyridoxine and biotin [25]. Medically, in [3,4] and [14], P. ostreatus has been reported to decrease cholesterol levels in experimental animals. [12] pointed out that the carpophore of the mushroom is also a potential source of lignin and phenol degrading enzymes.

[23] pinpoints that oyster mushrooms are grown from hyphae (threadlike filaments) that become interwoven into mycelium and propagated on a base of steam sterilized cereal grain usually sorghum, rye or millet. This myceliumimpregnated cereal grain is called spawn and is used to inoculate mushroom substrate [23]. Failure to achieve a satisfactory harvest may often be traced to unsatisfactory spawn used [7].

A number of materials, mostly agricultural wastes, can be used to prepare mushroom spawn. The type of waste available varies from region to region. Some of these wastes are chopped rice straw, sawdust, water hyacinth leaves, used tea leaves, cotton wastes and lotus seed husks [7]. In most laboratories, cereal grains such as wheat [10, 7, 27], rye [7], sorghum [7, 27], rice [19], millet [19, 10, 27] and white maize [27] are used as mother spawn.

Mushroom production relies on the mother spawn used. Thus, the need to introduce spawn production to farmers is found relevant to make mushroom available in the market.

\section{A. Literature Review \\ $>$ Mushrooms as a Source of Food}

[8] pointed out that man has been hunting for the wild mushrooms since antiquity. Thousands of years ago, fructifications of higher fungi have been used as a source of food [18] due to their chemical composition which is attractive from the nutrition point of view. During the early days of civilization, mushrooms were consumed mainly for their palatability and unique flavors [21, 22]. The early history regarding the use of mushrooms in different countries has been reviewed by number of workers [15]. [2] determined the nutritive value of Pleurotus flabellatus as $0.974 \%$ ash, $1.084 \%$ crude fibre, $0.105 \%$ fat, $90.95 \%$ moisture, $0.14 \%$ non-protein nitrogen and $2.75 \%$ protein. [1] suggested that food value of mushrooms lies between meat and vegetables. [9] observed that mushrooms in 
general contain $90 \%$ water and $10 \%$ dry matter. More so, the protein content varies between 27 and $48 \%$. Carbohydrates are less than $60 \%$ and lipids are between 2 to $8 \%$.

[20] indicated that an average mushroom is about $16.5 \%$ dry matter out of which $7.4 \%$ is crude fibre, $14.6 \%$ is crude protein and $4.48 \%$ is fat and oil. [13] indicated that edible mushrooms were highly nutritional and compared favourably with meat, egg and milk food sources. Of several thousand mushroom species known worldwide, only around 2000 are considered edible, of which about 20 are cultivated commercially with only 4 to 5 under industrial production [5]. There is also a significant difference in the nutrient contents of pileus versus stalks $[16,32]$.

\section{Carbohydrates}

[11] reported that Coprinus atramentarius (Bull.: Fr.) Fr. contain $24 \%$ of carbohydrate on dry weight basis. The mannitol, also called as mushroom sugar constitutes about $80 \%$ of the total free sugars, hence it is dominant $[28,30]$. Raffinose, sucrose, glucose, fructose and xylose are dominant in it [24]. Water soluble polysaccharides of mushrooms are antitumor [31].

\section{MATERIALS AND METHODS}

\section{A. Research Design}

The experiment was laid out using Completely Randomized Design (CRD) with four treatments. Each treatment was replicated three (3) times. There were four (4) varieties of mushroom used in the study such as Pleurotus florida, Pleurotus ostreatus, Ganoderma lucidum and Calocybe indica. Randomization was done through drawing of lots. Shown below are the treatments.

\begin{tabular}{|c|c|}
\hline Treatments & Description \\
\hline $\mathrm{T}_{1}$ & Pleurotus florida \\
\hline $\mathrm{T}_{2}$ & Pleurotus ostreatus \\
\hline $\mathrm{T}_{3}$ & Ganoderma lucidum \\
\hline $\mathrm{T}_{4}$ & Calocybe indica \\
\hline
\end{tabular}

*Treatment

Table 1:- Treatments

\section{B. Materials}

The following materials were used in this study: sorghum (Sorghum bicolor), flat bottles, sawdust, limestone, rice bran, polyethylene bags, rubber, cotton, paper, alcohol lamp, and denatured alcohol.

\section{Cultural Management}

\section{$>$ Washing and Sterilization}

During the experimental work, flat bottles were used. The glassware prior to use was washed with water and detergent powder followed by rinsing with tap water. The glasswares were dried and sterilized in pressure cooker for 30 minutes. The inoculation needle, knife, scissors, and blades were sterilized by dipping them in $70 \%$ alcohol followed by heating over flame.

\section{$>$ Preparation of Spawn}

Mother spawn was prepared from pure culture of four (4) strains $\left(T_{1}, T_{2}, T_{3}\right.$, and $\left.T_{4}\right)$ of mushroom. Grains were used as substrate for preparation of mother spawn. Clean, healthy, and bold grains were taken but broken and undersized grains were discarded then these were thoroughly washed in clean water three times to remove chaffs, dust, and other particles. Then, dipped in water for 30 minutes. The excess water was drained and grains were spread on clean cloth so that excess moisture can be eliminated. Total of $50 \mathrm{~g}$ of sorghum grains (Sorghum bicolor) were put into spawn bottles. About 2/3 of each spawn bottle was filled with grains and plugged with cotton, cover with aluminum foil and tied with rubber band. after they were sterilized in pressure cooker for 30 minutes. The grains in the bottles were then inoculated with mushroom strains of (Pleurotus florida) $\mathrm{T}_{1}$, (Pleurotus ostreatus) $\mathrm{T}_{2}$, (Ganoderma lucidum) $\mathrm{T}_{3}$ and (Calocybe indica) $\mathrm{T}_{4}$. under aseptic condition. After cooling, inoculation was done with active growing mycelium of four strains of mushroom then incubated at mushroom shed until the mycelium covered the entire grain surface. The spawn was prepared by this way called as mother spawn and prepared in sufficient quantity required for the proposed research work. For all kinds of studies, mother spawn was multiplied on wheat grains in similar way as described for mother spawn

\section{Data Gathering Procedures}

$>$ Yield Parameters

- Days of Mycelium Running. This was recorded by counting the number of days from inoculation to full colonization of the mycelia.

- Length of Mycelial Growth (cm). This was recorded by daily measuring the length of the mycelial growth from the bottom of the bottle to the middle of the spawn bottle using tape measure.

- Return on Investment (ROI). This was taken using the formula below.

$\mathrm{ROI}=\frac{\text { Net Income }}{\text { Cost of Production }} \times 100$

E. Data Analysis

$>$ Analysis of Variance (ANOVA) for Completely Randomized Design (CRD) were used as tool in determining the results of the study.

$>$ Duncan's Multiple Range Test (DMRT) was used to compare the significant differences among treatment means.

$>$ Profitability Using Return on Investment (ROI). This included all the inputs used for the study which begin from the spawn production to mushroom cultivation using the formula below:

$$
\mathrm{ROI}=\frac{\text { Net Income }}{\text { Cost of Production }} \times 100
$$




\section{RESULTS AND DISCUSSION}

\section{A. Length of Mycelia}

The linear regression of length of four (4) different mushroom varieties is presented in Figures 1, 2, 3, and 4. Pleurotus florida shows an increasing length of mycelia from day 3 to day 15 . The intercept was 0.9318 , meaning the increase brought was $0.9318 \mathrm{~cm}$ average per day with a very strong correlation (0.9913). Pleurotus ostreatus showed the same trend with Pleurotus florida with intercept or average increase per day of $0.9759 \mathrm{~cm}$. A very strong correlation was determined (0.9918). Ganoderma lucidum also showed an increasing length of mycelia from day 3 to day 15 . The intercept was 0.9412 , meaning the increase brought was $0.9412 \mathrm{~cm}$ average per day with a very strong correlation (0.99).

In addition, Calocybe indica revealed an increasing length of mycelia from day 3 to day 15 . The intercept was 0.9879 , meaning the increase brought was $0.9879 \mathrm{~cm}$ average per day with a very strong correlation (0.9931). Results of the study was observed having similar negative correlation and thus genetic diversity may play a key role on the mushroom production.

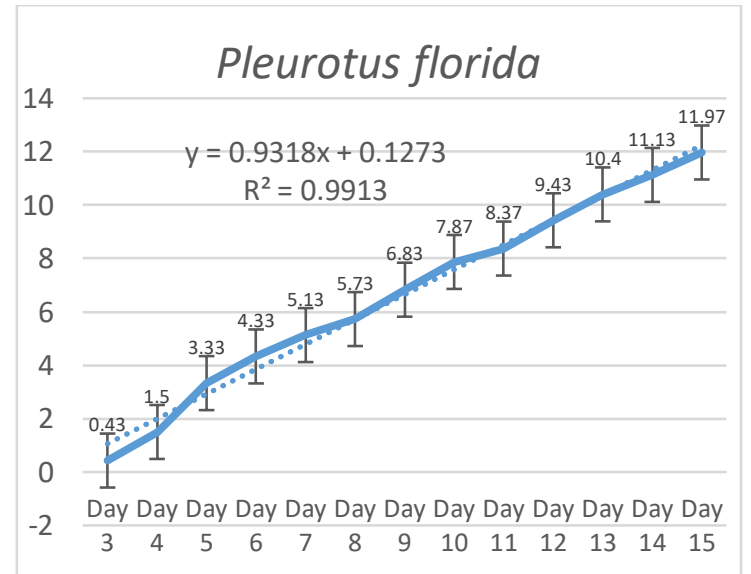

Fig 1:- Treatment 1 (Length of Mycelia)

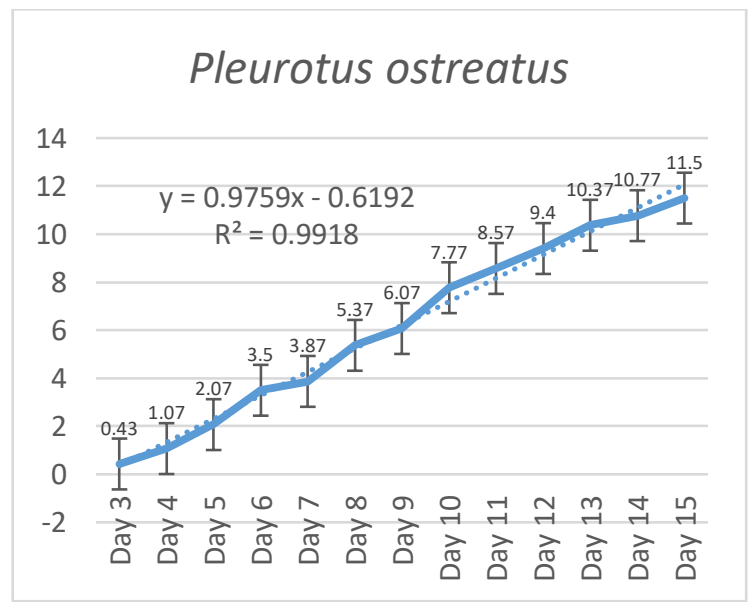

Fig 2:- Treatment 2 (Length of Mycelia)

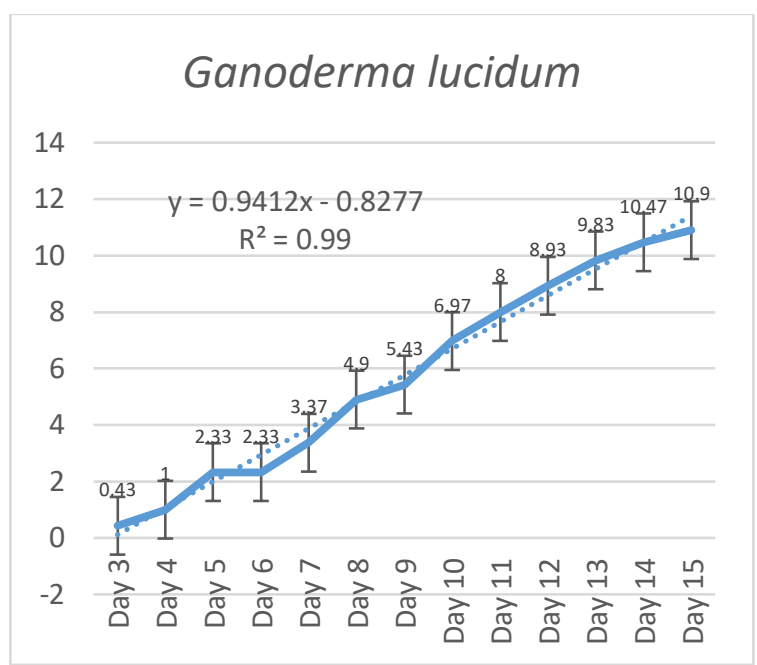

Fig 3:- Treatment 3 (Length of Mycelia)

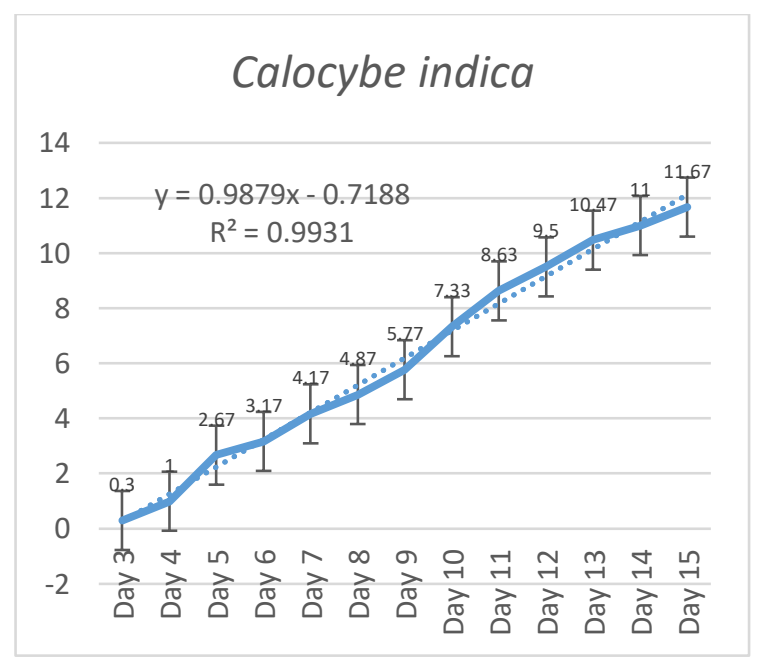

Fig 4:- Treatment 4 (Length of Mycelia)

\section{B. Width of Mycelia}

Pleurotus florida shows an increasing width of mycelia from day 6 to day 12 . The intercept was 0.9136 , with a very strong correlation (0.9569). Pleurotus ostreatus shows similar trend with $p$. florida with intercept or average increase per day of $1.035 \mathrm{~cm}$. A very strong correlation was determined among the mushroom variety used (0.9489). Ganoderma lucidum revealed an increasing width of mycelial growth from day 6 to day 12. The intercept was 0.9746 , meaning the increase brought was $0.9746 \mathrm{~cm}$ an average per day with a very strong correlation (0.9812). Calocybe indica also showed an increasing width of mycelia growth from day 6 to day 12 . The intercept was $1.1525 \mathrm{~cm}$, meaning the increase brought was $1.1525 \mathrm{~cm}$ an average per day with a very strong correlation $(0.9501)$. 


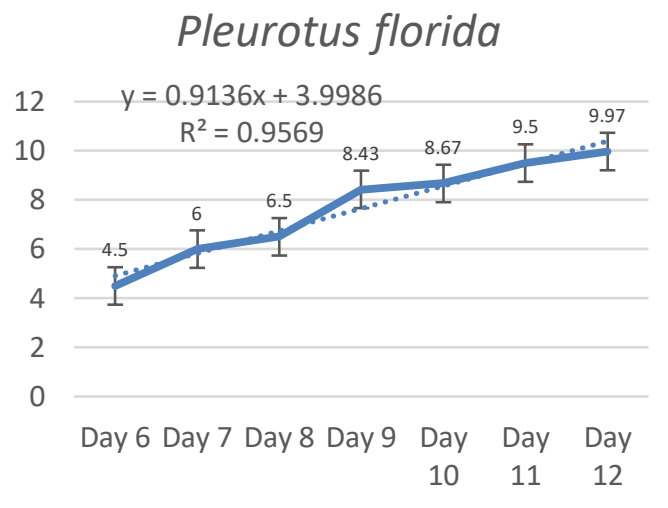

Fig 5:- Treatment 1 (Width of Mycelia)

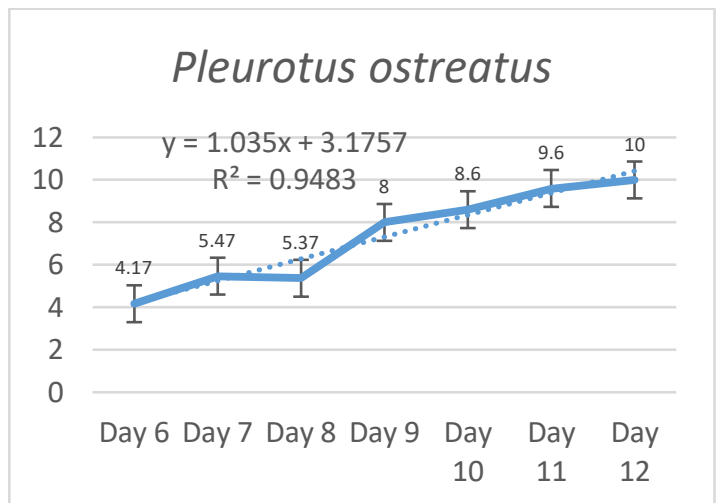

Fig 6:- Treatment 2 (Width of Mycelia)

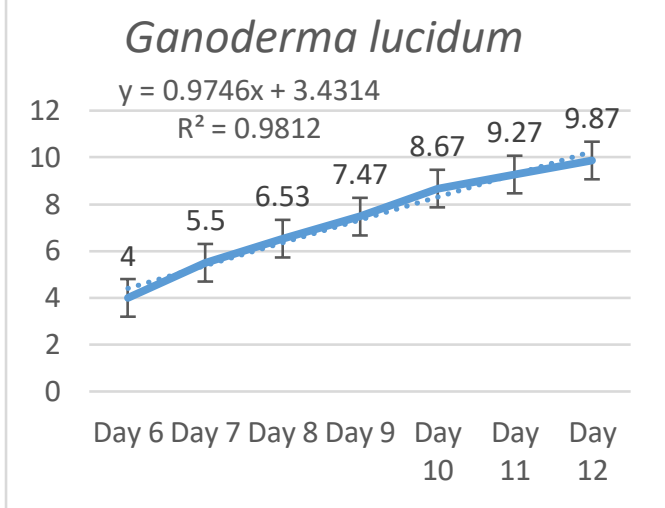

Fig 7:- Treatment 3 (Width of Mycelia)

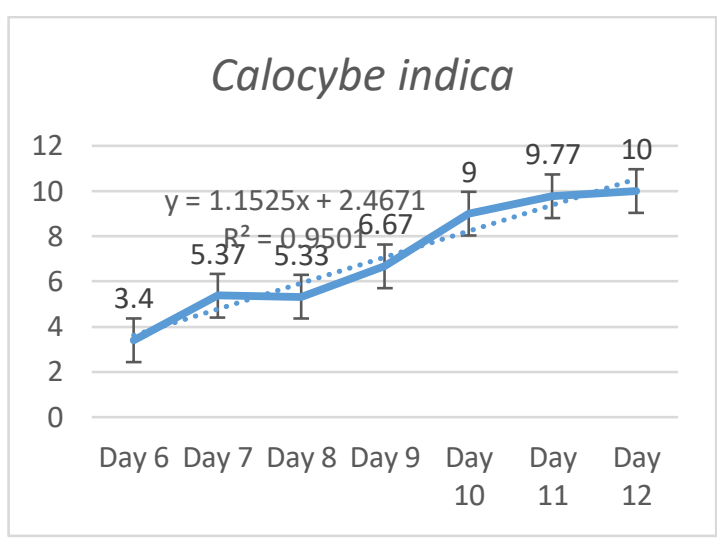

Fig 8:- Treatment 4 (Width of Mycelia)

\section{Return on Investment (ROI)}

The Return on Investment (ROI) of different varieties of mushroom is presented in Table 2. The same ROI was derived from three mushroom varieties namely Pleurotus ostreatus, $P$. florida and Ganoderma lucidum with $131.84 \%$. It shows that in every peso invested to these three varieties will give a return of $131.84 \%$. However, in terms of Calocybe indica, much lower, $127.58 \%$ ROI was recorded.

\begin{tabular}{|c|c|c|c|c|}
\hline & Pleurotus ostreatus & Pleurotus. florida & Ganoderma lucidum & Calocybe indica \\
\hline Pure culture (bottle) & 250.00 & 250.00 & 250.00 & 350.00 \\
\hline Cotton & 15.00 & 15.00 & 15.00 & 15.00 \\
\hline Tissue paper & 15.00 & 15.00 & 15.00 & 15.00 \\
\hline Detergent & 8.00 & 8.00 & 8.00 & 8.00 \\
\hline Rubber Band & 7.50 & 7.50 & 7.50 & 7.50 \\
\hline Bottle & 20.00 & 20.00 & 20.00 & 20.00 \\
\hline Aluminum foil & 17.00 & 17.00 & 17.00 & 17.00 \\
\hline Marker pen & 5.00 & 5.00 & 5.00 & 5.00 \\
\hline Rubbing alcohol & 50.00 & 50.00 & 50.00 & 50.00 \\
\hline Sorghum & 30.00 & 30.00 & 30.00 & 30.00 \\
\hline Denatured alcohol & 30.00 & 30.00 & 30.00 & 30.00 \\
\hline Rental & 200.00 & 200.00 & 200.00 & 200.00 \\
\hline $\begin{array}{l}\text { Total Cost of } \\
\text { production }\end{array}$ & 647.00 & 647.00 & 647.00 & 747.00 \\
\hline $\begin{array}{l}\text { Total Number of Bottled } \\
\text { Spawn }\end{array}$ & 10 & 10 & 10 & 10 \\
\hline Price per bottle & 150.00 & 150.00 & 150.00 & 170.00 \\
\hline Gross Income & $1,500.00$ & $1,500.00$ & $1,500.00$ & $1,700.00$ \\
\hline Net Income & 853.00 & 853.00 & 853.00 & 953.00 \\
\hline $\begin{array}{c}\text { Return on Investment } \\
(\%)\end{array}$ & 131.84 & 131.84 & 131.84 & 127.58 \\
\hline
\end{tabular}

Table 2:- Return on Investment of the Four Varieties of Mushroom (Pleurotus florida, Pleurotus ostreatus, Ganoderma lucidum and Calocybe indica). 
The result of the study showed that Pleurotus ostreatus, Pleurotus. Florida, and Ganoderma lucidum revealed similar findings in terms of return on investment with the $131.84 \%$. Thus, this is suggested in terms of ROI.

\section{CONCLUSION}

There is an increasing mycelial length of all the edible varieties from day 3 to day 15 . Significant mycelial length was recorded up to day 7 . As it grows to day $8-15$, no significant differences were recorded. The lengths of mycelia grow at an average of $0.93 \mathrm{~cm}$ for $P$. ostreatus, $0.96 \mathrm{~cm}$ for $P$. florida, $0.94 \mathrm{~cm}$ for $G$. lucidum and $0.98 \mathrm{~cm}$ for $C$. indica.

Width of mycelia was first recorded at day 6 . Recoding ended at day 12 because there was already similar width among edible mushrooms used. There are no significant differences among treatment means throughout the study. Width of mycelia had growth rate of $0.91 \mathrm{~cm}$, $1.03 \mathrm{~cm}, 0.97 \mathrm{~cm}$ and $1.15 \mathrm{~cm}$ for $P$. ostreatus, $P$. florida, G. lucidum and $C$. indica, respectively.

In addition, the same ROI was recorded for $P$. ostreatus, P. florida and G. lucidum while lowest ROI for $C$. indica was found in this study. This was due to higher pure culture price of the latter.

\section{REFERENCES}

[1]. Bano Z (1976). Nutritive value of Indian mushrooms and medicinal practices. Eco. Bot., 31: 367-371.

[2]. Bano Z, Srinivasan KS, Srivastava HC (1963). Amino acid composition of the protein from a mushroom (Pleurotus flabellatus). Appl. Microbiol., 11: 184-187.

[3]. Bobek, P., Ozdin, L. and Galbavy, S. 1998. Dose- and time-dependent hypercholesterolaemic effect of oyster mushroom (Pleurotus ostreatus) in rats. Nutrition 14: 282-286.

[4]. Bobek, P., Ozdin, O. and Mikus, M. 1995. Dietary oyster mushroom (Pleurotus ostreatus) accelerates plasma cholesterol turnover in hypercholesterolaemic rats. Physiological Research 44: 287-291.

[5]. Chang ST (1990). Future trends in cultivation of alternative mushrooms. Mush. J. 215: 422-423.

[6]. Chang ST, Miles PG (1992). Mushroom biology - A new discipline. Mycologist, 6: 64-65.

[7]. Chang, S. T. 2009. Training Manual on Mushroom Cultivation Technology, United Nations -Asian And Pacific Centre For Agricultural Engineering And Machinery (UN-APCAEM), Beijing, China.

[8]. Cooke RC (1977). Fungi, Man, and his Environment, Largman, London, New York, pp. 144.

[9]. Crisan EW, Sands (1978). A Nutritional value. In: Chang ST and Hayes WA (eds.). The biology and cultivation of edible mushrooms. Academic press, New York, pp. 172-189
[10]. Elhami, B. and Ansari, N. A. 2008. Effect of substrate of spawn production on mycelium growth of oyster mushroom species. Journal of Biological Sciences 8(2): 474-477.

[11]. Florezak J, Karmnska A, Wedzisz A (2004). Comparision of the chemical contents of the selected wild growing mushrooms. Bromatol. Chem. Toksykol., 37: 365-371.

[12]. Fountoulakis, M. S., Dokianakis, S. N., Kornaros, M. E., Aggelis, G. G. and Lyberatos, G. 2002. Removal of phenolics in olive mill wastewaters using the whiterot fungus Pleurotus ostreatus. Water Research 36: 4735-4744.

[13]. Gruen VEC, Wong HX (1982). Immunodulatory and Antitumour activities of a polysaccharide-peptide complex from a mycelial culture of Trichoderma sp. Sciences, 57: 269-281.

[14]. Hossain, S., Hashimoto, M., Choudhury, E., Alam, N., Hussain, S., Hasan, M., Choudhury, S. and Mahmud, I. 2003. Dietary mushroom (Pleurotus ostreatus) ameliorates atherogenic lipid in hypercholesterolaemic rats. Clinical and Experimental Pharmacology and Physiology 30: 470.

[15]. Houghton W (1995). Notices of fungi in the Greek and Latin Author Ann. Mag. Nat. His., 15: 22-29.

[16]. Latifah AL, Abu Bakar MD, Abu BM (1996). Relative distribution of minerals in the pileus and stalk of some selected edible mushrooms. Food Chem., 56: 115-121.

[17]. Lindequist, U., Niedermeyer, T. H. J. and Julich, W. 2005. The pharmacological potentials of mushrooms. eCAM 2: 285-299.

[18]. Mattila P, Konko K, Eurola M, Pihlawa JM, Astola J, Vahteristo Lietaniemi V, Kumpulainen J, Valtonen M, Piironen V (2001). Contents of vitamins, mineral elements, and some phenolic compounds in cultivated mushrooms. J. Agric. Food Chem., 49: 2343-2348.

[19]. Oei, P. (1996). Mushroom cultivation with special emphasis on appropriate techniques for developing countries. CTA, The Netherlands.

[20]. Orgundana SK, Fagade O (1981). The nutritive value of some Nigerian edible mushrooms. In: Mushroom Science XI, Proceedings of the Eleventh International Scientific Congress on the Cultivation of Edible Fungi, Australia, pp. 123-131.

[21]. Rai RD (1994). Nutritional and medicinal values of mushrooms. In: Advances in Horticulture. (Chadha KL, Sharma SR eds.), Malhotra publishing house, New Delhi, pp. 537-551.

[22]. Rai RD (1997). Medicinal mushrooms. In: Advances in Mushroom Biology and Production (Rai RD, Dhar BL, Verma RN ed.) Mushroom society of India. NRCM, Solan, H.P., pp. 355-368.

[23]. Royse, D. J. 2003. Cultivation of Oyster Mushrooms. Pennsylvania State University Press, Pennsylvania.

[24]. Singh NB, Singh P (2002). Biochemical Composition of Agaricus bisporus. J. Indian Bot. Soc., 81: 235-237.

[25]. Solomko, E. F. and Eliseeva, G. S. 1988. Biosynthesis of vitamins B by the fungus Pleurotus ostreatus in a submerged culture. Prikladnaia Biokhimiia i Mikrobiologiia 24(2): 164-169. 
[26]. Stamets, P. 2000. Growing Gourmet and Medicinal Mushrooms. 3rd edn. California, Berkley: Ten Speed Press.

[27]. Stanley, H. O. 2010. Effect of substrates of spawn production on mycelial growth of oyster mushroom species. Agriculture and Biology Journal of North America 1(5): 817-820.

[28]. Tseng YH, Mau JL (1999). Contents of sugars free amino acids and free 5- nucleotides in mushroom, Agaricus bisporus, during the post-harvest storage. J. Sci. Food Agric., 79: 1519-1523.

[29]. Tsioulpas, A., Dimou, D., Iconomou, D. and Aggelis, G. 2002. Phenolic removal in olive oil mill wastewater by strains of Pleurotus spp. in respect to their phenol oxidase (laccase) activity. Bioresource Technology 84: 251-257.

[30]. Wannet WJB, Hermans JHM, Vander Drift C, Op den Camp HJM (2000). HPCL detection of soluble carbohydrates involved in mannitol and trehalose metabolism in the edible mushroom, Agaricus bisporus. J. Agaric. Food Chem., 48: 287-291.

[31]. Yoshioka Y, Ikekawa T, Nida M, Fukuoka F (1975). Studies on antitumor activity of some fractions from basidiomycetes I. An antitumor acidic polysaccharide fraction of Pleurotus ostreatus (Fr.) Quel. Chem. Pharm. Bull., 20: 1175-1180.

[32]. Zakia SA, El-Kattan MH, Hussein WA, Khaled AM (1993). Chemical composition and processing potential of oyster mushroom, Pleurotus ostreatus. Egypt J. Agric. Res., 71: 621-631. 